\title{
Sasha Grey, Sigmund Freud and Johann Wolfgang Won Goerte: The Primal Scene Revisited-A Case Report*
}

\author{
James Bozzuto \\ University of Connecticut, Connecticut, USA
}

\begin{abstract}
There is a vast number of studies and a plethora of scholarly literature on various aspects of pornography and particularly Internet pornography. Most have focused on the negative outcomes related to individual functioning. There are few that examine the consequences for the offspring of Internet pornography performers. Freud postulated that for children who become "witnesses of sexual intercourse between their parents", the primal scene, "arrive in every case at the same conclusion. They adopt what might be called a sadistic view of coition” (Freud, 1908, p. 220). One hundred years later, these observations and conclusions need to be reconsidered. In our current social media climate, more and more of our lives are being recorded in perpetuity. The Internet is everywhere and forever (Paul, 2005). YouTube, Twitter, Flicker, cell phone cameras, etc., provided the technology for recording and storing our everyday lives in ways that were unimaginable 20 years ago. Our private sexual lives can be recorded and viewed by adults and children. Individuals who work in pornography are creating a lasting legacy that will be viewed by their children and will have lasting effects on those children. These children certainly be exposed to the primal scene and the lasting psychological sequela will be profound. A single case report will be presented and an actual performer will be profiled.
\end{abstract}

Keywords: Sasha Grey, pornography, primal scene, children of pornography actors

\section{Freud and Goethe}

Goethe (1906), in Faust, has Mephistopheles say, “After all, the best of what you know, may not be told to boys" (Freud, 1900, p. 142).

Children are unprepared for comprehending adult sexuality. Society has universally condemned the participation in, the viewing, commercial sale or trafficking of children in sex and pornography for good reason. It is a heinous crime that destroys young lives. The consequences of sexual abuse of children, or not protecting children from sexual abuse, are well known to the clinician.

It will not stop the intense interest and healthy curiosity in children and adolescents in sex. Adult mature sexuality is achieved by gradual assimilation of materials and experiences from various appropriate sources at age appropriate levels. When children are exposed to materials that are overwhelming, and not age appropriate, various misunderstandings arise, defenses are erected to protect the individual, and psychopathology is the result.

Sometimes, children are inadvertently exposed. Freud was the first to examine the effects of these

\footnotetext{
* The third Biennial International, Multidisciplinary Conference, “EROS 2010” Nipissing University, Muskoka Campus, Braceland, Ontario, Canada, May 21-22, 2010.

James Bozzuto, assistant clinical professor, Department of Psychiatry, University of Connecticut.
} 
inadvertent events on children. When children view explicitly the sexual activity of adults, it is beyond their comprehensions, and they will conclude various distortions. Freud (1908) labeled this the primal scene, and responsible parents go to great lengths to conceal this activity. In the "Sexual Theories of Children", Freud (1908) stated:

The third of the typical theories arises in children if, through some chance domestic occurrence, they become witnesses of sexual intercourse between their parents. Their perceptions of what is happening are bound, however, to be only very incomplete. Whatever detail it may be that comes under their observation-whether it is the relative positions of the two people, or the noises they make, or some accessory circumstance-children arrive in every case at the same conclusion. They adopt what may be called a sadistic view of coition. They see it as something that the stronger participant is forcibly inflicting on the weaker, and they (especially boys) compare it to the romping familiar to them from their childish experience-romping which, incidentally, is not without a dash of sexual excitation. I have not been able to ascertain that children recognize this behavior which they have witnessed between their parents as the missing link needed for solving the problem of babies; it appears more often that the connection is overlooked by them for the very reason that they have interpreted the act of love as an act of violence. (pp. 220-221)

Thus, Freud reminded us, that the primal scene, has intense and lasting consequences. Most important, it will be retained and distorted. Freud's concept of "Traumatic Neurosis" (Vol. 19) and the "Stimulus Barrier (Furst)", had not yet been formulated when he defined the primal scene. If he had conceived these later ideas at the same time he conceptualized the primal scene, he would probably expanded concepts with a different language. Using those formulations, the primal scene would present the child with psychological information that would easily overwhelm the undeveloped ego of he/she and present it with materials that could not be digested and overcome the stimulus barrier and produce what we call today PTSD (post traumatic stress disorder). In adults, PTSD is produced in adult minds with some self-regulating capacity and ability to adapt. In children, there is no such hope. Children and adolescents cannot comprehend adult sexuality, which will lead to overstimulation and distortion.

Primal scene occurrences continue today and we would perhaps interpret the consequences differently than Freud in 100 years ago (Knafo \& Feiner, 1996). The age of the child, the quality of the relationship between adults (Holt, 1980), the explanatory capacity of the parents, the previous sexual education of the children, are just a few of the considerations that would mitigate distortions (Blum, 1979). However, no parent would willing expose their child to viewing the primal scene, as the consequences would be overwhelming and grossly inappropriate. Longitudinal, prospective studies have examined early childhood exposure to parental nudity and scenes of parental sexuality and concluded that there may be increased risk of STD (sexually transmitted diseases) transmission and becoming pregnant (Okami, 1988).

But as traumatic or not, the accidental primal scene, does not compare to viewing parental sexual behavior recorded on the Internet forever. Explicit sexuality of parents, with strangers, for money, will have a different impact. The Internet will preserve these images, in a manner, that an accidental intrusion into the parental bedroom will not. More important, the mass distribution of this material to friends, peers, family members, employers, teachers, etc., multiplies the consequences of the primal scene and ensures it will be experienced over and over for many years.

Goethe, wrote Faust, in 1806, approximately 200 years ago. Faust is Goethe's most famous work and may be one of the greatest works of German literature. Widely referenced in our culture, one theme remains current. How much would you sell your soul to the devil? What price would induce you to engage in behavior you would not ordinarily do? The Faustian bargains we all engage in every day are familiar. Would I cheat to get 
ahead, would I embezzle to enjoy the indulgences of money now? Madoff made the ultimate Faustian deal, to enjoy infinite wealth for many years, all the while knowing that the devil was coming for his due.

Young adults, usually women in their teens enter pornography with the promise of a lucrative career and fame. Eighteen is not the best age to understand the consequences of one's actions. One of the unintended consequences of pornography is that the sexual behavior of these individuals will be viewed by their children which has significant negative impact on these children. The Faustian bargain, 200 years old, still has its payback. The bargain that young woman make was best described by Goethe with the inevitable outcome of "infanticide".

Faust makes an arrangement with the devil: The devil will do everything that Faust wants while he is here on Earth, and in exchange Faust will serve the devil in Hell. The pact is signed in blood. Faust has a few excursions and then meets Margaret (also known as Gretchen). He is attracted to her and with jewelry and help from a neighbor, Marthe, the devil draws Gretchen into Faust's arms. Faust seduces Gretchen and they sleep together. Gretchen's mother dies from a sleeping portion, administered by Gretchen to obtain privacy, so that Faust could visit her. Gretchen discovers that she is pregnant. Gretchen's brother condemns Faust, challenges him and falls dead at the hands of Faust and the devil. Gretchen drowns her illegitimate child and is convicted of the murder (retrieved from http://en.wikipedia.org/wiki/Goethe\%27s_Faust).

The Faustian bargain that woman who work in pornography, now has to include the inevitable negative consequences on their children. No longer can the immaturity of our young adulthood be hidden from our children. The Internet will preserve our activities and definitely be a part of our children's legacy. Infanticide will be the consequence of these families; faulty superego formation will lead to concrete problems manifest as acting out and the inevitable adolescent problems of STD's, drug abuse, pregnancy and suicide.

\section{Sasha Grey}

Sasha Grey is arguably the most popular pornographic performer in the US industry today. She planned a career in her teens and on the day of her 18th birthday, moved to Los Angeles and recorded her first porn film. From a poor family in Sacramento, her father left when she was five years old, and her mother remarried when she was 12 years old. She had experienced divorce, poverty and isolation. She stated that she felt miserable at home around her step father and informed her mother that she was going to move out at 16 . She attended four high schools before graduating, unhappy in each one. She attended junior college and took classes in film, dance and acting. She waited tables, saved \$7,000 and moved to L.A. when she was at the age of 18.

In an interview, her first agent disclosed that she was the perfect porn teen, willing to do anything (the author's interview). Her first scene was an orgy for the Fashionistas 2. When she was younger, prior to her video career, she dated a cook at the steak house where she worked, who introduced her to slapping and other kinds of consensual degradation during sex. In that first scene, she asked the lead male actor to punch her in the stomach hard. Within weeks of turning 18, she was booked solid for months and has continued a highly productive volume of material. She has appeared in well over 200 videos, probably 100 in her first year of work. An attractive and intelligent woman, her reputation remains as one performer who will do anything. Much of her scenes involve graphically sadistic sex, and particularly violence towards woman. Either administering or receiving pain has been her specialty. Her most popular videos involve graphic sadomasochistic sex that she said enhance the sexual experience. She never used condoms and has experienced at least three episodes of 
STD's (Williamson).

Outside the film studio, she has received high acclaim by the adult film industry. Less that a year after entering the industry, in January of 2007, Grey was the recipient of awards for "Best Three Way Sex Scene", and "Best Group Scene" at the AVN adult movie awards. She was nominated as "Best New Starlet". In 2008, she became the youngest person to win the AVN "Female Performer of the Year" award. That same year, she won the award of "Best Oral Sex Scene" for a scene, in which she performed oral sex on four men (retrieved from http:en.wikipedia.org/wiki/Sasha_Grey).

She has also become the face of the industry, appearing on multiple national TV shows. She has advocated and promoted herself cleverly as the "spokeswoman" for sexual freedom and is now a frequent speaker at age 21 in numerous college campuses, including Brandeis and Yale. She has also become a director of pornographic films, recruiting young woman to star in her films. She presented herself as the philosophical pornographic actor, and appeared holding a copy of Nietche's books.

Recently in January 2010, she appeared at "Sex Week" at Yale, and in an interview, when asked what she hoped students would take away from her talk, she replied, "People at my age are uncomfortable with their sexuality, and I want to change that". She also talked about her plans for life after porn. She said she hopes to start a family some day. "Obviously, I will not be performing in adult films then" (retrieved from http://www.Nathan Harden).

\section{Case Presentation}

A 35 years old woman presented to an outpatient psychiatric clinic with a chief complaint of difficulty functioning in law school as a first year student. She described an inability to focus on her course work and increasing depression. She had a past history of episodic depression. She reported a four week symptom complex of difficulty concentrating, anxiety and lack of sleep. Another focus was concern about her 15 years old daughter. The mother reported that the daughter was doing well, socially and academically until a few months ago. Rather abruptly, the daughter's academic performance had severely deteriorated: She was truant frequently and was experimenting with drugs and sex. She was expelled from a private school the previous year and enrolled in a new public school this year.

The patient reported that this was causing her to be distracted from her demanding studies. The patient also had marital problems. She had married to a man who had two teenage sons a few months ago. They set up a blended household. She complained that her husband was excessively controlling, which centered on her activities of going out to bars with her ex-boyfriends during the week. She would get dressed up provocatively, to go out with the ex-boyfriends and found the husband's objections unacceptable. She felt she could see anyone she wanted and thought that her husband was over-reacting and being overly possessive.

In review of the initial diagnostic presentation, the question arose of the reason why this teenage daughter had decompensated now. Adolescent problems usually reflect issues in the family. In subsequent sessions, questions were raised concerning raising three adolescents in a new, blended family. She revealed, after my inquires, that physical fights were common and she had found her 15 years old daughter and the 16 years old stepson kissing and touching. There was no strong response from the mother. The author wondered how boundaries were maintained with three teenagers living in a small home without the incest barrier to maintain distance. She described her parenting style as "more like friends" and did not feel that strict rules and boundaries were necessary in raising children. 
The author felt that meeting the patient and her husband now was necessary to obtain a more comprehensive view of the marriage and the family, and arranged a meeting with them both. He seemed like a reasonable man, who was stressed as he was a student also. He understood the necessity of placing limits on his two sons and had no problem imposing reasonable limits, but was ineffective and blocked from intervening with the patient's daughter. The patient's focus in this meeting was not on her daughter, but was on her request for her husband to not be "possessive", as she was demanding her freedom to see other men. She expected the author to support her in her demands.

These issues of a blended family, with three adolescents without clear boundaries, seemed like a precipitating issue for the daughter. A few weeks after the first visit, the mother related that things had further deteriorated: The daughter was arrested on school grounds for disrupting classes, threatening other students and teachers, and eventually had to be subdued by four policemen. She was found to have illicit drugs in her system and was hospitalized on an adolescent psychiatric unit for one week. In addition, she faced criminal charges surrounding the incident at school.

Following discharge, the daughter was referred for outpatient treatment in a therapeutic school while awaiting rulings in her police cases. The daughter was placed with the maternal grandmother, where there could be more supervision.

Over the course of the next several months, and a developing therapeutic alliance, the patient revealed more of her history, haltingly and in fragments. As an only child, she was raised in an affluent suburban community. Her mother was a professional and her father died when she was a teenager. She left home at age of 17 after having conflict with her mother, and moved to New York city to live on her own. She drank excessively and used drugs. She would not be more specific. She got pregnant, had a daughter at age of 20, and moved with her to California. The father was not involved in the child's upbringing.

The author's patient's daughter, like most 15-year-olds, was active in various social networking sites. One month after the daughter's hospitalization, multiple unknown people sent the daughter pornographic images and videos of her mother. They were also sent to the daughter's peers, and mother's teachers, school and employers. The mother had failed to tell the author that as a 21-year-old, she had worked in the pornography industry. As a performer, she had made some shoots in California, traveled to Europe and made movies there also. She was not sure if this was the first time the daughter had been exposed to these materials, as she had never shared this history with the daughter.

After this exposure of her past, the patient was concerned mainly about her own career. "This is terrible” as she was afraid for her own education and being suspended from school. There was no discussion of the child, or the problems which might be caused to her daughter. The author was not sure how this child handled her peers, and their comments or behavior. The patient's response to her daughter's discovery of her on Facebook, engaged in various scenes, some portraying sadistic and masochistic contents (that was one of her specialties), was, “now maybe she will believe me more, when I tell her I don't want her to make the same mistakes I have”. At the author's urging and concern for the child, she was encouraged to speak to the daughter about the daughter's feelings and the inevitable conflicts that would create for the daughter. There was no real discussion, but she felt relieved that the daughter professed that "she still loved me". Around this time, the daughter had a pregnancy scare. She was not on any birth control. She was found not to be pregnant, but told her mother that the only thing she wanted to do in her life was having a baby and hoped it would happen sooner rather than later. She had not approached the topic again with her daughter. The daughter 
continued to live with her grandmother and saw her mother every few days. There were currently no plans for her to move back with mother.

The daughter was never interviewed, but was receiving appropriate psychiatric care. The husband was referred, as he requested for help. The main focus of our therapy was exclusively with the patient and being able to function in school, without the disruptions from her daughter.

\section{Discussion}

This case illustrated one of the consequences of permanently recording sexual activity of parents on their children. Our patient, when raising an adolescent girl, hoped (denied) that her prior sexual activity would not become public for her daughter to view. However, the primal scene was revisited, to child, friends, teachers, employers, etc.. A chapter of her young sexual activities, including pornography, was now made available to her daughter and the world.

Superego lacunae is a term that implies faulty development in an otherwise well-functioning superego. Parents, who transmit these absences to their children, do so consciously and unconsciously. Parents who lie, cheat, steal generally do not place limits on their children's behaviors in these areas. Children, who push every boundary naturally to test limits, find that they are given permission to pursue these activities without guilt. This patient rationalized her behaviors and never anticipated its consequences. By rationalizing her own behaviors, she showed poor judgment and poor limit setting with her teenage girl. By placing a 15-year-old in a living situation with two boys at her own age, she was subjecting the girl to a potentially dangerous sexual situation. Finding the girl and one of the boys "making out" did not bring the appropriate response. By demanding to her husband that she should be allowed to spend evenings with old boyfriends, she was demanding a certain freedom in marriage that usually results in disaster. Only when the child was removed from the family and placed in the custody of the grandmother, did the girl settle down.

The adolescent was not interviewed for this report. During her formative and early explorative sexual attempts at experimentation, she must have experienced her mother's lack of concern and limit setting. Now, to be exposed to the explicit, graphic, pornographic activities of her mother, can only imply permissiveness. The mother's videos were of a sadistic and masochistic nature. Superego formation in children is an almost a direct transplant, especially in single-parent families. As she watched her mother perform, one can only guess the curiosity, intensity and "misunderstanding in a 15-year-old's mind". There will be no limitations, no prohibitions and no moral sense of wrong-doing.

The fragility of adolescence was further compounded by the exposure of these materials from the mother's past to peers, teachers, friends and other children who were not always supportive. Children are highly stimulated by adult sexual behavior and they will seek it out. We also know children can be very cruel. Boys may project onto this child that she will be permissive like her mother, and girls may be either attracted or repulsed by her mother's activity. Either way, the result is that teenagers will be over-stimulated and not able to comprehend, no matter how they pretend to be mature.

The amount of trauma that a child will experience in this situation will vary with the age of the child. At nine or ten, it is predicted that older students will become aware of the sexual behavior of a sexual performer and identify the child of that mother. The Internet makes this relatively easy. The older children will not be kind, and the inevitable cruelty, teasing, harassing and bullying can be predicted. They will be truly victims no matter how their parents prepare them or support them. 
At true adolescence, the chorus of singling out and identifying these children by other children cannot be escaped. They may choose to defend their mothers, but that will place them in an untenable position. As they experiment with sexuality, their mothers' behaviors, as recorded in the Internet, will play some part. It is predicted that internal limit setting would be a problem for the child.

As adults, we are responsible for our behaviors and accept society's response to them. That is adulthood. But as children, we have no choice. We are exposed to our parents' mores and values, and society's response to our parents' values. Society can be very cruel, and some of the basest comments are to teenagers by other teenagers who are perceived to be loose with their sexuality. But even more harsh words and deeds are reserved for parents who expose their children to explicit sexual images, especially of the parents themselves. There will also be distorted interactions with other families. Will other mothers allow their daughters to spend sleepovers with a mother who is a porn star? Will other fathers linger longer at the soccer match or school function with the porn star? Will teachers treat the child of a porn star differently? The answer is yes, and the child will perceive the difference. Celebrities create special problems for their children, most of which can be overcome. Porn stars create a different legacy, one that the author thinks is destined to produce PTSD in their children, no matter how it is handled, and it is just too much to ask an adolescent to integrate.

In Sasha Grey's case, her graphic, sado-masochistic and "free" sexuality with multiple partners, male and female, were forever available. As a teenager, she made a pact to advance her career doing "whatever it takes", without regard to future children. She now plans a family. Her children will not have to wait 15 years to view her sexuality; it is available all over the Internet now and they will be exposed to it.

Like Rebecca in Faust (1806), Sasha has "killed" her Irish Catholic mother, and now commits infanticide. There is no way her future children can escape the "sins of the father". They will be exposed from infantacy. Sasha is the most recognizable porn star in the US and she actively promotes herself.

The author has worked with many men and women who have been arrested for child pornography and sex with underage children. Most are drawn in by the naïve hope that their Internet or actual activities will remain hidden. That is not the case anymore, as law enforcement agencies have become more adapt at tracking and uncovering these dangers. Even soliciting underage children is dealt with harshly and appropriately. If a parent was found exposing their child to pornography, that child would be removed from the home. We now have cases where parents are recording their pornography for profit. At this digital age, we can reasonably assume their children will view these materials, which will definitely disrupt the normal, phase-specific development of children in catastrophic ways.

This case represents only one episode of Internet pornography of a mother and the consequences for her adolescent daughter. Is it a crime to promote the primal scene, especially with strangers, for money, with multiple partners, on the Internet? If parents showed pornographic materials to children, they would be arrested. One analogy would be to seat belts. Twenty years ago, many parents did not strap their kids in or use different seats. With scientific evidence showing the dangers, the legal system has made it a crime to expose children to the dangers of driving children without the proper restraints. Should pornographic performers have to protect their children, and how would one install "seat belts" on pornography?

These women, one probably hoping to avoid the past, the other actively promoting pornography, raise questions about society's response to pornography. Should all porn performers be required to undergo counseling before they start a career? Should they be advised that their activity will have adverse consequences on their children? The lack of supervision in the industry allows 18-year-olds to perform in an industry that 
some label sex trafficking. And is the self-promotion, on college campuses and national TV, of activity that harms children to be encouraged? Should future families of performers of pornography be registered as potential persons who place their children at "risk of injury to minors"? Should they and their children be monitored by social service agencies as we do with sex offenders? Are these children at an exceptionally high risk for psychological problems precipitated by the behavior of their parents? Are they PTSD victims at birth?

Goethe understood, and Freud recorded. Sexuality is not appropriate for children. They are too immature for exposure to adult sexuality, which will only lead to over stimulation, lack of integration, distortion and trauma. A parent's responsibility is to protect children from exposure, be it the primal scene, pornography or their parents' engagement in pornography. Performers who record permanent images of their sexual activities will now know that there will be future negative consequences for their children. Cultural institutions will have to define where this stand in the spectrum of restricted behavior and sexual abuse, and are universally united in protecting children from harm; women will take the lead on this issue.

\section{References}

Blum, H. P. (1979). On the concept and consequences of the primal scene. Psychoanalytic Q., 48(1), 27-47.

Freud, S. (1908). On the sexual theories of children. In J. Strachey (Ed. \& Trans.), The standard edition of the complete psychological works of Sigmund Freud (Vol. IX, p. 220). London: Hogarth Press.

Freud, S. (1917-1919). An infantile neurosis and other works. In J. Strachey (Ed. \& Trans.), The standard edition of the complete psychological works of Sigmund Freud (Vol. XVII). London: Hogarth Press.

Freud, S. (1900). Distortion in dreams. In J. Strachey (Ed. \& Trans.), The standard edition of the complete psychological works of Sigmund Freud (Vol. IV). London: Hogarth Press.

Furst, S. (1967). Psychic trauma, basic books. New York.

Gunderson, J. G., \& Zanarini, M. C. (1989). Pathogenesis of borderline personality. In A. Tasman, R. E. Hales, A. J. Frances (Eds.), Review of psychiatry (Vol. VIII, pp. 25-48). Washington, D. C.: American Universtiy Press.

Hoyt, M. F. (1979). Primal-scene experiences: Quantitative assessment of an interview study. Archives Sex Behavior, 8(3), 225-45.

Holt, M. F. (1980). On the psychology and psychopathology of primal-scene experience. Journal of the American Academy of Psychoanalysis, 18(3), 311-35.

Kalman, T. P. (2008). Clinical encounters with Internet pornography. J. Amer. Acad. of Psychoanalysis and Dymanic Psychiatry, 36(4), 593-618.

Knafo, D., \& Feiner, K. (1996). The primal scene. Journal of the American Psychoanayticl Assoc., 44(2), 549-69.

Okami, Olmstead, R., Abramson, P. R., \& Pendleton. L. (1998). Early childhood exposure to parental nudity and scenes of parental sexuality (“primal scenes”): An 18-year longitudinal study of outcome. Archives. of Sexual Behavior, 27(4), 361-384.

Paul, P. (2005). Pornified: How pornography is transforming our lives, our relations-ships and our families. New York: Times Books, Henry Holt and Company.

Peto, A. (1975). The etiological significance of the primal scene in perversions. Psychoanalytic Q., 44(2), 177-90. 